\title{
Spondyloarthritides: evolving therapies
}

\author{
Andrew Barr* and Andrew Keat
}

\begin{abstract}
TNF blockade therapy has substantially advanced the treatment of peripheral spondyloarthritides but revolutionised the treatment of severe ankylosing spondylitis. The capacity of biologic treatment to improve dramatically symptoms and quality of life in patients with spinal disease is undoubted, although important questions remain. Notable amongst these are concerns about skeletal disease modification and the true balance between costs and effectiveness. Guidelines for the biologic treatment of ankylosing spondylitis and psoriatic arthritis have been introduced in North America and Europe with considerable consensus. However, the absence of clear criteria for the diagnosis of early disease leaves the issue of biologic treatment of ankylosing spondylitis at the preradiographic stage unresolved. Newer biologic agents are entering the field, although superiority over TNF blockers will be difficult to demonstrate.
\end{abstract}

\section{Introduction}

The introduction of TNF-blocking biologic drugs has constituted the greatest advance in the treatment of spondyloarthritis (SpA) over the past 50 years. At last, SpA - so long the Cinderella compared with rheumatoid arthritis - has entered the limelight with many patients previously untreated or unrecognised seeking the new magic bullet. The availability of effective anti-TNF treatment has exposed the personal and societal economics of treating and failing to treat these disorders as well as their impact on individual lives.

New treatments have complemented advances in understanding of pathological changes in SpA, especially the key role played by enthesitis in peripheral and spinal lesions. New imaging techniques have made it clear that ankylosing spondylitis (AS), although identified historically by

\footnotetext{
*Correspondence: barrandrew@aol.com

Rheumatology Department, Northwick Park Hospital, Harrow, Middlesex HA1 3UJ, UK
}

classic radiographic change, is a continuum from a preradiographic phase to a radiographic phase - the whole continuum being appropriately referred to as Axial SpA [1]. During the radiographic phase, skeletal lesions are probably irreversible and may progress independently of ongoing inflammation; conversely, the opportunities for prevention or reduction of skeletal damage may be found during the pre-radiographic phase, although recognition of disease at this time is problematic. At this early stage, acute inflammatory lesions may be widespread and fluctuating throughout the spine [2,3]; the transformation of these acute lesions to more chronic fatty bone and entheseal lesions may be what promotes the formation of new bone and hence ankylosis. It is therefore likely that treatment of spinal inflammation and symptoms may come to be divorced from therapeutic prevention of skeletal damage.

\section{Limitations of conventional approaches to treatment}

The crucial importance of new and emerging therapies in the field of SpA is best seen in the context of the shortcomings of current conventional treatment approaches. Undoubtedly nonsteroidal anti-inflammatory drugs reduce symptoms of AS and their continuous use may reduce the rate of ankylosis [4], but the mechanism of such an effect is not clear. Conventional diseasemodifying anti-rheumatoid drugs (DMARDs), however, exert neither symptomatic nor disease-modifying effects on the spine - and although used for treatment of peripheral joint disease, evidence of efficacy is limited. The evidence for efficacy of various medications on SpA has been summarised [5] and Assessment of Spondyloarthritis International Society (ASAS)/European League Against Rheumatism (EULAR) treatment recommendations have been made [6].

In spite of evidence linking infection with the pathogenesis of both axial and peripheral SpA, notably reactive arthritis, the potential efficacy of antimicrobial therapy on the course of SpA remains uncertain. The evidence of efficacy of antimicrobial treatment of reactive arthritis has been reviewed elsewhere [7]. In both peripheral and axial SpA, therefore, there is a strong desire for more effective symptom-controlling agents and a need for drugs that truly modify disease outcome. 
Table 1. Key outcome measures in common use for assessment of axial disease in ankylosing spondylitis

\begin{tabular}{|c|c|c|c|}
\hline Outcome & Instrument & Main components & Reference \\
\hline \multirow[t]{5}{*}{ Disease activity } & BASDAI & $\begin{array}{l}\text { Self-administered VAS questionnaire: fatigue, axial pain, peripheral joint pain, tenderness, } \\
\text { stiffness }\end{array}$ & [99] \\
\hline & ASAS $20,40,70$ & $\begin{array}{l}\text { Percentage improvement in three out of four domains: patient global, pain, function and } \\
\text { inflammation }\end{array}$ & {$[100,101]$} \\
\hline & ASAS 5/6 & $>20 \%$ improvement in all four ASAS domains + one of CRP or metrology & [101] \\
\hline & Partial remission & $<20 \%$ activity in all four ASAS domains & [100] \\
\hline & ASDAS & Includes CRP & [102] \\
\hline \multirow[t]{3}{*}{ Physical function } & BASFI & Self-administered VAS questionnaire: 10 questions about day-to-day tasks & [103] \\
\hline & Dougados index & Self-administered VAS questionnaire: 20 questions about day-to-day tasks & [104] \\
\hline & HAQ-S & Self-administered questionnaire scoring difficulty of 25 day-to-day tasks & [105] \\
\hline \multirow[t]{2}{*}{ Metrology } & BASMI & $\begin{array}{l}\text { Five clinical measurements: cervical rotation, tragus to wall distance, lateral lumbar flexion, } \\
\text { modified Schober's, intermalleolar distance }\end{array}$ & [106] \\
\hline & EDASMI & $\begin{array}{l}\text { Four clinical measurements: cervical rotation, lateral lumbar flexion, chest expansion, and } \\
\text { internal rotation of the hip }\end{array}$ & [107] \\
\hline Spine X-ray score & mSASSS & Disease of anterior vertebral corners on a lateral cervical and lumbar radiograph & [108] \\
\hline \multirow[t]{3}{*}{ Spine MRI score } & Berlin Score & Vertebral junction disease by quantifying bone marrow oedema & [109] \\
\hline & ASspiMRI-a & Vertebral junction disease by quantifying bone marrow oedema and erosions & [110] \\
\hline & SPARCC Index & Vertebral junction disease by quantifying bone marrow oedema & [111] \\
\hline \multirow[t]{3}{*}{ Work } & AS-WIS & A simple 20-item questionnaire to measure work instability in AS & [112] \\
\hline & WPAl-SHP & Quantitative measure of reduced productivity, both at work and during nonwork activities & [113] \\
\hline & Questionnaire & & \\
\hline \multirow[t]{2}{*}{ Health-related quality of life } & ASQoL & Addresses symptoms, function and disease-related concern & [114] \\
\hline & SF-36 & Physical and mental health assessment & [115] \\
\hline
\end{tabular}

AS, ankylosing spondylitis; ASAS, Assessment of Spondyloarthritis International Society; ASDAS, Ankylosing Spondylitis Disease Activity Score; ASQoL, Ankylosing Spondylitis Quality of Life; ASspiMRI, Ankylosing Spondylitis Spine MRI score; AS-WIS, Ankylosing Spondylitis Work Instability Scale; BASDAI, Bath Ankylosing Spondylitis Disease Activity Index; BASFI, Bath Ankylosing Spondylitis Functional Index; BASMI, Bath Ankylosing Spondylitis Functional Index; CRP, C-reactive protein; EDASMI, Edmonton Ankylosing Spondylitis Metrology Index; HAQ, Health Assessment Questionnaire; MRI, magnetic resonance imaging; mSASSS, Modified Stoke Ankylosing Spondylitis Spinal Score; SF-36, Short-form 36; SPARCC, Spondyloarthritis Research Consortium of Canada; VAS, visual analogue scale; WPAI-SHP, Work Productivity and Activity Impairment-Specific Health Problem Questionnaire.

\section{Key outcome measures}

Recent studies have done much to identify and measure the outcomes of treatment of SpA for the purposes of both research and clinical practice. The development of valid, reproducible and objective assessments of axial disease (spondylitis) has been especially difficult, although valuable instruments have been devised by several groups notably from Bath in the UK and by the ASAS, hence use of the prefixes Bath and ASAS. Further development of truly objective measures remains desirable. The key measures most used in spondyloarthritides are described in the ASAS handbook for assessment in SpA and elsewhere [8,9]. Table 1 presents a summary of the key outcomes for assessment of axial disease in AS.

\section{Biologic treatment of spondyloarthritides}

The key therapeutic development in SpA is the introduction of TNF blockade therapy. Other agents, including orally administered drugs, may enter the field in the near future but the present review focuses on the biologic agents studied and used thus far in the treatment of SpA. Separate consideration of treatment of axial and peripheral disease is appropriate.

\section{Axial spondyloarthritis}

The biologic agents studied and used in the treatment of axial SpA are presented in Table 2.

The TNF blockers have become well established in the management of SpA and key aspects of their use and efficacy are summarised below. Comparability between studies is hampered by use of a range of different measures and by variations in study design, although there are clear anti-TNF class effects with relatively small differences in efficacy between agents.

\section{Axial disease activity}

Reductions in evidence of disease activity - notably pain, stiffness and fatigue - are achieved by all TNF blocking agents studied; comparable responses in the ASAS 20, ASAS 40 and ASAS 5/6 and the Bath Ankylosing 
Table 2. Biological agents in ankylosing spondylitis

\begin{tabular}{|c|c|c|c|c|c|}
\hline Name & Biologic class & Half-life & Administration & Frequency & $\begin{array}{l}\text { Published randomised } \\
\text { control trial data }\end{array}$ \\
\hline Infliximab & Chimeric TNF inhibitor & 8 to 9 days & Intravenous & Every 6 to 8 weeks & 5 years $[11]$ \\
\hline Etanercept & Fusion protein TNF inhibitor & 70 hours & Subcutaneous & Twice a week or weekly & 5 years [92] \\
\hline Adalimumab & Fully human TNF inhibitor & 2 weeks & Subcutaneous & Fortnightly & 3 years [38] \\
\hline Golimumab & Fully human TNF inhibitor & 2 weeks & Subcutaneous & Every 4 weeks & 24 weeks [14] \\
\hline Rituximab & Anti-CD20 (anti- $\beta$ cell) & 3 weeks & Intravenous & Two doses & 24 weeks [15] \\
\hline Ustekinumab & Fully human IL-12 and IL-23 inhibitor & 3 weeks & Subcutaneous & Every 4 weeks in psoriatic arthritis & None \\
\hline Anakinra & IL-1 inhibitor & 4 to 6 hours & Subcutaneous & Daily & 24 weeks [17] \\
\hline
\end{tabular}

Spondylitis Disease Activity Index (BASDAI) 50 have been achieved by adalimumab, etanercept and infliximab. These responses are achieved as early as 2 weeks after treatment [10]. It is clear that a BASDAI 50 response is maintained at 1 year by 47 to $58 \%$ of patients and an ASAS 20 response at 2 years by 65 to $83 \%$ of patients. Partial remission is maintained by one-third of patients at 2 and 3 years [11-13]. Reductions in the BASDAI and achievement of ASAS criteria based on intention to treat data are summarised from representative studies in Table 3.

Preliminary data are available for several other biological agents. Efficacy of golimumab, a fully humanised TNF inhibitor, is comparable with other TNF inhibitors over the short term [14] but longer-term experience is awaited. Rituximab, in a 24-week phase II trial (see Table 2), was as effective as TNF inhibitors in anti-TNFnaïve patients with active AS but appeared ineffective in patients who had failed such treatment [15]. Limited data on use of anakinra have suggested less significant benefits in the treatment of AS $[16,17]$, and reports of the use of other biologic agents are anecdotal.

Magnetic resonance imaging (MRI), using the Ankylosing Spondylitis Spine MRI score, has established that the acute changes of spinal inflammation respond well to anti-TNF $\alpha$ therapy. A reduction in MRI signs of spinal inflammation of the order of 40 to $50 \%$ was seen after 3 months of treatment with infliximab, and this reduction persisted after 2 years. At this point, however, there was some residual spinal inflammation in approximately $80 \%$ of patients [18]. Significant improvement in the Ankylosing Spondylitis Spine MRI score with etanercept treatment has been seen as early as 12 weeks, and this benefit was maintained at 6 months [19]. Similar improvement in spinal and sacroiliac inflammation was seen in adalimumab-treated patients using the Spondyloarthritis Research Consortium of Canada scoring method. This benefit was maintained at week 52 of therapy [20].

Both infliximab [21] and adalimumab [22] have been shown to be effective at controlling symptoms and ameliorating MRI spinal changes in early disease (axial
SpA), although any long-term disease-modifying effect has yet to be observed. The likelihood of clinical response to anti-TNF has been found to be greater in patients with shorter disease duration [23].

\section{Function, work and productivity}

Improvement in function, as measured by the Bath Ankylosing Spondylitis Functional Index, is seen as early as 2 to 12 weeks after initiation of TNF blockade therapy $[10,24,25]$ and is maintained for at least 3 to 5 years $[11,12]$.

This functional improvement is rapidly reversed on early discontinuation of treatment. Greater functional improvement is more likely to occur in those patients with early disease; these data should be seen in the context of the natural progression of untreated or conventionally treated disease, in which one estimate indicates natural progression of functional deterioration at 0.05 Bath Ankylosing Spondylitis Functional Index units per year [26].

Although separately measured, a close associate of function is the capacity for work and productivity. AS is associated with substantial work disability and loss of work productivity [27]. Work capacity also correlates with quality-of-life measures such as the Ankylosing Spondylitis Quality of Life [28]. Self-reported improvement in work capacity has been noted as early as 24 weeks after anti-TNF therapy [29], and return to work of some patients has been reported after a mean of 18 months of therapy [30]. This clearly has important implications for individual income, self-esteem and family welfare in addition to assessment of the costeffectiveness of these agents.

\section{Health-related quality of life}

Treatment with each of the available anti-TNF agents has been associated with significant improvement in the physical component of the Short-form 36 (SF-36) score. Improvement occurs between 6 and 12 weeks [10,24] and is maintained in long-term trials [11]. Nonsignificant improvements in the mental component scores also 
Table 3. Intention to treat data for infliximab, etanercept and adalimumab

\begin{tabular}{|c|c|c|c|c|c|c|c|c|c|}
\hline Disease measure & Drug & $\begin{array}{c}\text { Week } 0 \\
(\%)\end{array}$ & $\begin{array}{c}\text { Week } 2 \\
(\%)\end{array}$ & $\begin{array}{c}\text { Week } 6 \\
(\%)\end{array}$ & $\begin{array}{c}\text { Week } 12 \\
(\%)\end{array}$ & $\begin{array}{c}\text { Week } 24 \\
(\%)\end{array}$ & $\begin{array}{c}\text { Year } 1 \\
(\%)\end{array}$ & $\begin{array}{c}\text { Year } 2 \\
(\%)\end{array}$ & $\begin{array}{c}\text { Year } 3 \\
(\%)\end{array}$ \\
\hline \multirow[t]{3}{*}{ BASDAI 50} & Infliximab [24,93-95] & 0 & 41 & $\sim 58$ & 53 & & 47 & 41 & 47 \\
\hline & Etanercept [25] & 0 & & 57 & 71 & & & & \\
\hline & Adalimumab [13] & 0 & & & 43 & 51 & 56 & 59 & \\
\hline \multirow[t]{3}{*}{ ASAS 20} & Infliximab [37,71] & 0 & $\sim 50$ & $\sim 61$ & $\sim 62$ & $\sim 61$ & & 74 & \\
\hline & Etanercept $[96,97]$ & 0 & 53 & & 60 & $\sim 76$ & & 83 & \\
\hline & Adalimumab $[10,13]$ & 0 & $\sim 42$ & $\sim 56$ & 58 & 65 & & 65 & \\
\hline \multirow[t]{3}{*}{ ASAS 40} & Infliximab [93,95] & 0 & & $\sim 32$ & 50 & 47 & $\sim 54$ & 52 & 50 \\
\hline & Etanercept [97] & 0 & & & 49 & $\sim 64$ & $\sim 62$ & & $\sim 66$ \\
\hline & Adalimumab [13] & 0 & & $\sim 35$ & & 46 & & 51 & \\
\hline \multirow[t]{3}{*}{ ASAS 5/6 } & Infliximab [93] & 0 & & $\sim 34$ & $\sim 63$ & $\sim 52$ & 53 & $\sim 48$ & 46 \\
\hline & Etanercepta $[98]$ & 0 & & $\sim 50$ & $\sim 69$ & $\sim 60$ & 65 & & \\
\hline & Adalimumab [13] & 0 & & $\sim 37$ & 48 & 59 & $\sim 55$ & 59 & \\
\hline \multirow[t]{3}{*}{ ASAS Partial Remission } & Infliximab [71] & 0 & $\sim 10$ & $\sim 17$ & $\sim 21$ & 22 & $\sim 23$ & $\sim 29$ & \\
\hline & Etanercept ${ }^{a}[98]$ & 0 & & 31 & 31 & $\sim 27$ & 31 & & \\
\hline & Adalimumab [13] & 0 & & $\sim 20$ & 21 & 24 & & 34 & \\
\hline
\end{tabular}

Intention-to-treat data from randomised control trials and open-label extensions based on duration of anti-TNF therapy for infliximab, etanercept and adalimumab. ASAS, Assessment of Spondyloarthritis International Society; BASDAI, Bath Ankylosing Spondylitis Disease Activity Index. ${ }^{\mathrm{a} E t a n e r c e p t ~ A S A S ~ 5 / 6}$ and partial remission intention-to-treat data are from patients recommencing etanercept after withdrawing for several months after a 6-month randomised control trial with etanercept.

occur. Improvement in well-being is also reflected by significant improvement in Ankylosing Spondylitis Quality of Life, which is maintained in long-term trials [13].

Fatigue and sleep disturbance are important features of active AS. All anti-TNF agents are associated with improvement in fatigue, as reflected by reduction in the BASDAI fatigue scale, and improvement of sleep, using the Jenkins sleep scale, has been reported with golimumab treatment [14].

\section{Spinal movements}

Improvement in metrology has been modest in most studies of TNF blockade therapy, reflecting both the extent of irreversible disease and insensitivity of this measure. Some improvement in the Bath Ankylosing Spondylitis Metrology Index (BASMI) score may be seen as early as 2 to 12 weeks [10,24,25], and this is sustained in most patients. It is clear, however, that maintenance of improvement in spinal mobility requires sustained regular mobilisation exercises.

\section{Disease modification of radiographic disease progression}

Assessing disease progression in axial SpA is an imperfect art. Methods for scoring disease progression are problematic [31]. The modified Stoke Ankylosing Spondylitis Spine Score [32] is currently the most sensitive to change of the methods and is therefore the radiographic method of choice for detecting radiographic progression [33]. Reliance on anterior changes at two segments of the spine and exclusion of the posterior elements and thoracic segment are, however, undoubted limitations. Assessment of disease progression has also been hampered by lack of long-term follow-up of randomised controls on both ethical and practical grounds. Treatment groups have therefore been compared with historical control groups such as the Outcome Assessments in Ankylosing Spondylitis International Study cohort, in which patients received nonsteroidal anti-inflammatory drugs, analgesics and regular exercise therapy. Acknowledging these limitations, no significant difference has been detected in disease progression (modified Stoke Ankylosing Spondylitis Spine Score) between patients with active AS treated with etanercept, adalimumab or infliximab therapy compared with controls [34-36].

\section{Treatment regimes and responsiveness}

Currently it appears probable that most patients will require indefinite treatment, although dropout-rate 
ranges from 8 to $16 \%$ per year are described $[12,37,38]$. Stopping treatment appears to allow relapse in almost all patients [39] but most patients respond again on retreatment. Everyday clinical experience, however, indicates that some patients are able to withdraw treatment for periods of months and occasionally indefinitely. There are few data to clarify the numbers of patients in whom drug-free remission may be expected or the characteristics of patients in whom achievement of this is likely. Results of on-demand treatment led to results that were inferior to those of regular treatment [40].

Response to anti-TNF treatment in AS is greatest in patients with short-duration disease [23], high BASDAI and high acute phase markers, in particular C-reactive protein [41]. Biomarkers predictive of responsiveness to treatment or other outcomes have not clearly been identified; serum levels of metalloproteinase-3 may predict radiographic progression in AS [42]. Failure of the first anti-TNF drug does not predict success or failure of switching to a second or third anti-TNF drug [43-45].

\section{Peripheral spondyloarthritis}

Few studies have focused specifically on these lesions within the context of $\mathrm{SpA}$, the majority of studies of peripheral SpA addressing psoriatic arthritis (PsA). It is not clear to what extent data on this condition are applicable to the generalisation of peripheral SpA; nor is it clear whether data on small joint polyarthritis are applicable to large joint oligoarthritis. With these caveats, however, it is reasonable to summarise the position in PsA and the disparate data of other peripheral SpA lesions, with the expectation that many conclusions are broadly applicable to peripheral SpA with or without axial or other associated lesions.

\section{Psoriatic arthritis}

As in AS, the difficulties of developing robust diagnostic criteria and appropriate disease-specific outcome measures have recently been partially overcome by the work of the Classification of Psoriatic Arthritis CASPAR international study group and the Group for Research and Assessment of Psoriasis and Psoriatic Arthritis $[46,47]$. The former has developed and validated a simplified and highly specific set of diagnostic criteria that distinguishes PsA from non-PsA with a sensitivity and specificity of 0.914 and 0.987 , respectively [46]. The Group for Research and Assessment of Psoriasis and Psoriatic Arthritis has also established evidence-based practice recommendations for treatment of PsA based on a systematic literature review of each manifestation along with a consensus opinion by both rheumatologists and dermatologists [48]. Pharmacological therapies include nonsteroidal anti-inflammatory drugs, intraarticular steroids, DMARDs and biological therapies. In a meta-analysis of conventional DMARDs and anti-TNF agents in PsA, the three licensed TNF blocking drugs were found to have efficacy/toxicity ratios that were superior to conventional DMARDs as either monotherapy or combination therapy [49]. Available data do not differentiate between adalimumab, etanercept and infliximab so far as efficacy in PsA is concerned [50,51]. Each has demonstrated efficacy in terms of disease activity and symptom control, health-related quality of life and function and modification of disease progression. Table 4 presents a summary of the key outcomes for assessment of PsA.

\section{Disease activity}

Etanercept treatment has led to significant improvement in both arthritis and skin symptoms in patients with PsA [52]. Further studies have shown that $60 \%$ of those receiving etanercept achieved an American College of Rheumatology (ACR) 20 response, with one-quarter of eligible patients achieving a $75 \%$ reduction in the Psoriasis Area and Severity Index (PASI). ACR 20 criteria, Psoriatic Arthritis Response Criteria, and PASI 50 criteria were met by $64 \%, 84 \%$, and $62 \%$, respectively, of patients receiving etanercept at the end of the 48-week open-label period [53]. Approximately $80 \%$ of patients meet Psoriatic Arthritis Response Criteria by 4 weeks, and substantial falls in the PASI are seen by 24 weeks of treatment. Comparable ACR and Psoriatic Arthritis Response Criteria responses have also been demonstrated with infliximab [54] and adalimumab [55]. Comparable outcomes over 24 weeks have been reported recently with golimumab, with approximately $50 \%$ achieving ACR 20 responses and concomitant improvements in PASI, nail involvement (NAPSI) and a PsA-modified version of the Maastricht Ankylosing Spondylitis Enthesitis Scale (MASES) [56]. Although originally devised and validated for rheumatoid arthritis, the Disease Activity Score is also frequently used in the assessment of PsA - although this is inappropriate for patients with oligoarticular disease.

Data from the British Society for Rheumatology Biologics Register indicate that advancing age, female gender and corticosteroid therapy were associated with poorer clinical response rates [51].

\section{Differing treatment regimes}

In clinical trials most data have been obtained from patients receiving TNF blockers and methotrexate in combination. It is clear, however, that TNF blockade alone is effective treatment for PsA [57] and the place of monotherapy versus combination therapy for PsA has yet to be fully defined.

In observational studies, switching between the three licensed anti-TNF agents due to adverse events or loss of efficacy has conferred improvement in clinical outcomes 


\begin{tabular}{|c|c|c|c|}
\hline Outcome & Instrument & Main components & Reference \\
\hline \multirow[t]{6}{*}{ Disease activity } & Composite measures & & \\
\hline & $\begin{array}{l}\text { ACR } 20,50 \\
70 \text { response }\end{array}$ & $\begin{array}{l}\text { Percentage improvement in tender and swollen joint counts in addition to } \\
\text { improvement in three out of five measures: physician's and patient's assessment } \\
\text { of disease activity, patient's assessment of pain, acute phase reactant, and } \\
\text { functional questionnaire }\end{array}$ & [116] \\
\hline & PSARC & $\begin{array}{l}\text { Improvement by }>1 \text { point in both physician's and patient's assessment of disease } \\
\text { activity in addition to }>30 \% \text { reduction in tender and swollen joint counts }\end{array}$ & [117] \\
\hline & Skin disease & & \\
\hline & PASI 50, 75 & Percentage improvement in severity and extent of skin involvement & [118] \\
\hline & Minimal disease activity & $\begin{array}{l}\text { Having five of the following seven criteria: tender joint count }<1 \text {; swollen joint } \\
\text { count }<1 \text {; PASI }<1 \text { or body surface area }<3 \text {; patient pain VAS }<15 \text {; patient global } \\
\text { disease activity VAS }<20 \text {; health assessment questionnaire }<0.5 \text {; and tender } \\
\text { entheseal points }<1\end{array}$ & [119] \\
\hline Radiograph scoring & Sharp score & Joint erosion + joint narrowing scores & [120] \\
\hline
\end{tabular}

ACR, American College of Rheumatology; PASI, Psoriasis Area and Severity Index; PSARC, Psoriatic Arthritis Response Criteria; VAS, visual analogue scale.

when switching from the first to the second agent, but larger trials are required to confirm this effect [58].

\section{Health-related quality of life and physical function}

Improvement in physical disability, in terms of improvement in the Health Assessment Questionnaire score, has been widely reported in response to anti-TNF therapies, although this is partially dependent upon the pretreatment state. Randomised control trial data for antiTNF agents confirm improvement in the physical component of the SF-36 and Health Assessment Questionnaire $[55,56,59]$ and the SF-36 mental component with infliximab [55,56,59]; these effects are maintained in follow-up trials for up to 2 years [60-62]. Adalimumab, etanercept and infliximab are associated with similar responses in terms of quality of life (SF-36) and functional status (Health Assessment Questionnaire) in normal clinical practice [63].

\section{Radiographic disease progression}

Conventional DMARDs have not been shown to induce significant inhibition of radiographic disease progression. In contrast, studies with adalimumab, etanercept and infliximab have all demonstrated inhibition of radiological progression as evidenced by plain radiography scoring. Mease and colleagues reported a greater inhibition of radiographic progression in etanercept therapy versus placebo therapy at 1 year, with a mean unit change in total sharp score of -0.03 and +1.00 , respectively [53]. Patients completing 2 years of etanercept had a mean adjusted change in total Sharp score of -0.38 from baseline [64]. Equally effective inhibition of structural damage has been reported with infliximab [65] and adalimumab [66] up to 2 years. It is not clear whether concomitant methotrexate enhances this effect or helps to maintain efficacy.

\section{Reactive arthritis}

In spite of the concept that reactive arthritis is initiated and driven by persistent bacterial infection, evidence that this is so or that the course of the disease is influenced by antimicrobial treatment is limited and controversial. Studies of short-term and long-term antibiotic monotherapy have indicated both the presence and lack of clinical efficacy [7]. Establishing or refuting a role for antibiotic treatment in reactive arthritis is hindered by the lack of a gold standard diagnostic test to identify a presumed causal microorganism(s) and to demonstrate its eradication by appropriate treatment. Evidence relating to persistent infection in reactive arthritis has focused principally on Chlamydia trachomatis and Chlamydia pneumoniae. These organisms are known to possess the property of persisting in synovial tissue in a metabolically active state. A recent randomised control trial of patients with chronic reactive arthritis and detectable chlamydial DNA in synovial biopsy or blood demonstrated significantly greater clinical response and probability of eradication of chlamydial DNA amongst patients randomised to combination antibiotic treatment compared with placebo [67]. Further studies are required to establish the role of antibiotics in the treatment of reactive arthritis.

Anecdotal reports on the use of anti-TNF therapy in a few patients with severe, chronic reactive arthritis suggest value [68], although the possibility of persistence of viable microorganisms within the joint and elsewhere raises the prospect of potentially serious sepsis with increased morbidity.

\section{Undifferentiated peripheral spondyloarthritis}

Treatment of peripheral SpA is usually influenced or constrained by the associated key SpA conditions, with the exception of undifferentiated forms of peripheral 
SpA. Although criteria for diagnosis of peripheral SpA arthritis are clear [69], validated disease outcome measures for peripheral $\mathrm{SpA}$ are limited. It remains unclear whether treatment of SpA at an undifferentiated stage influences the subsequent development of irreversible differentiated disease.

Anti-TNF treatment is associated with substantial sustained reductions in tender and swollen peripheral joint counts [70,71], although longer-term outcome data on subsequent need for surgery are awaited. It may be reasonable to transfer conclusions drawn from studies in PsA (vide supra) to other forms of peripheral SpA but, in reality, much information is still missing. In particular, data on the efficacy of TNF blockade with respect to rapidly progressive hip destruction, which is a key indicator of bad prognosis in SpA, would be of great value.

In clinical practice, large joint monoarthritis, especially of the knee, remains a challenging problem that may not respond well to either conventional or biologic therapy. Current guidelines do not recommend anti-TNF treatment for monoarthritis as the potential value in this context is unknown. Anecdotal accounts of intraarticular instillation of TNF-blocking agents into the knee of patients with AS and refractory peripheral monoarthritis indicate short-term value only [72].

\section{Enthesitis}

Clinically relevant enthesitis lesions are common throughout SpA, with up to $50 \%$ of patients with AS experiencing symptomatic enthesitis at some time $[73,74]$. For many, conservative measures are adequately effective although the small benefit afforded by sulphasalazine does not justify the side-effect profile [75].

Evidence of efficacy of biologic treatment of enthesitis has been obtained principally from observations of concomitant peripheral enthesis lesions during studies of AS or PsA, with no clear data on treatment of severe individual lesions such as Achilles' tendonitis. Short-term randomised controlled trials of 12 and 24 weeks of treatment demonstrated significant improvement in enthesitis [10,24]; and in the open-label Rhapsody trial of adalimumab treatment of AS, MASES scores were reduced from a mean of 5 at baseline to 1 at the 12th week: 122 of 173 patients had resolution of plantar fasciitis over the same time frame [70].

\section{Uveitis}

While topical corticosteroids and mydriatics remain the primary treatment of anterior uveitis, anti-TNF therapies may be of value in those with recurrent or especially severe episodes. Meta-analysis of the use of infliximab and etanercept in treatment of AS showed that both agents significantly reduced the frequency of episodes of uveitis compared with placebo therapy, conferring an incidence of anterior uveitis of $3.4 / 100$ patient-years, 7.9/100 patient-years and $15.6 / 100$ patient-years, respectively [76]. Similarly, adalimumab treatment has also been associated with a reduced incidence of acute anterior uveitis from 15 to 7.4/100 patient-years [77].

Retrospective analysis of the use of adalimumab, etanercept and infliximab in the treatment of spondyloarthritides indicated that etanercept treatment led to a smaller reduction of uveitis flares than the other two agents studied and, in addition, flares of uveitis have been reported in patients starting etanercept therapy. Data for newer anti-TNF agents are awaited. It is not clear to what extent TNF blockade is appropriate for treatment of isolated uveitis in patients without other SpA features.

\section{Newer biologic agents}

It is clear that the licensed TNF-blocking drugs provide substantial benefit for many, but by no means all, patients and that newer anti-TNF drugs are likely to share class effects. A number of newer licensed biologic agents are also effective in improving recognised disease outcomes for joint disease and/or co-morbidities, although the range of clinical benefits seen thus far with anti-TNF drugs will be hard to match or exceed.

\section{TNF-blocking drugs}

Of the newer TNF-blocking agents, golimumab - a human anti-TNFa monoclonal antibody - has been shown to achieve ACR responses similar to those achieved with other TNF blockers in the treatment of people with PsA and is generally well tolerated [56]. Treatment is also associated with improvement in healthrelated quality of life (SF-36) and function (Health Assessment Questionnaire). Effectiveness in short-term trials of treatment for AS has already been cited above. Information about the efficacy of certolizumab pegol is awaited.

It is well recognised that new agents entering the field face particular challenges as recruitment to clinical trials is increasingly likely to include subjects with milder, less typical or more resistant disease. In consequence, data should be compared with earlier anti-TNF studies with some caution.

\section{Non-TNF-blocking agents}

Ustekinumab, an anti IL-12/IL-23 monoclonal antibody, has been shown - in a placebo-controlled randomised study of 70 patients with PsA - to be associated with significant improvement in five out of seven of the ACR component scores at week 12 of therapy. Reductions in the C-reactive protein level and swollen joint count did not achieve significance in the treatment arm [78]. Ustekinumab has demonstrated efficacy in most patients 
with moderate to severe psoriasis in phase III trials [79]. IL-10 treatment showed some improvement in skin disease (PASI) but no improvement in measures of PsA in a small, double-blind, placebo-controlled study in patients with PsA [80]. Alefacept, a fully human fusion protein that inhibits leucocyte function by binding to $\mathrm{CD} 2$ on the surface of $\mathrm{T}$ cells, is an effective treatment of moderate to severe chronic plaque psoriasis [81]. In a recent study, combined with methotrexate, similar ACR and PASI responses to those obtained with anti-TNF treatment were demonstrated [82]. The safety profile also appears similar, so this agent appears promising for the treatment of both skin and musculoskeletal disease.

No randomised control trial data for abatacept or tocilizumab in the context of SpA have yet been reported.

\section{Safety of biologic agents in spondyloarthritis}

The safety profile of the widely used TNF $\alpha$ blocking agents has been extensively documented in the treatment of rheumatoid arthritis; safety data are also extensive in SpA but less complete. Long-term studies with infliximab, etanercept and adalimumab in AS and PsA have revealed mostly mild to moderate adverse events, including upper respiratory tract infections, diarrhoea, headache and injection-site reactions [11-13,59,60,64,83]. A recent analysis of data from the British Society for Rheumatology Biologics Register has confirmed that TNF $\alpha$ blocking agents in PsA have a similar adverse event profile and incidence of malignancy to DMARD therapy in seronegative arthritis [51]. Further studies of adequate statistical power and duration are required, however, before excluding a carcinogenic property of these drugs in SpA.

Other biologic agents have been less thoroughly evaluated. In the predominantly young SpA population, effects on cardiovascular risk and pregnancy are especially relevant. Accelerated atherosclerosis is likely to be the major contributor to increased standardised mortality rates seen in the spondyloarthritides. Provisional data from open-label studies have reported significant amelioration of the proatherogenic lipid profile and acute phase reactants of 92 patients with highly active AS after 3 months of etanercept [84], although it is not clear whether such changes will confer cardiovascular disease protection.

Use of any biologic drug in pregnancy is not supported. Data on fertility and teratogenicity have generally been drawn from non-SpA populations, although it is clear that foetal and maternal risks are small with TNF blockade treatment. Decisions about cessation or introduction of anti-TNF treatment in both men and women when pregnancy is desired or possible should be made on an individual basis taking into account known risks and maternal health [85].
This article is part of a review series on Progress in spondylarthritis, edited by Matthew Brown and Dirk Elewaut. Other articles in the series can be found online at http://arthritis-research.com/series/ spondylarthritis.

\section{Guidelines for treatment of spondyloarthritis with biologic agents}

Guidance regarding the use of anti-TNF agents in the treatment of AS $[26,86,87]$ and PsA $[9,88-90]$ have been issued by several national and international agencies. Consensus on the classification of pre-radiographic axial SpA [91] may lead to revised regulatory decisions on the use of TNF blockade treatment in early AS with radiographic changes.

\section{Conclusion}

It is clear that TNF blockade treatment exerts a profound beneficial effect on symptoms in the majority of, but not all, patients with severe SpA. It is also clear that peripheral joint damage is significantly reduced by treatment, although this appears not to be the case for spinal disease. There is thus a need both to establish the case for early treatment that will prevent, rather than minimise, joint damage and to understand the reasons for apparent lack of damage prevention in spondylitis.

Inevitably availability of biologic therapy is and will remain restricted on the bases of potential toxicity and cost. Thus better targeting of treatment through use of clinical criteria and biomarkers is essential to ensure that only those who need them receive biologic drugs. Such need must be based both on the biology of the disease and on the life quality of the individual. Prevention of damage can surely underpin a better lifestyle and perhaps a longer life in good health. But attaining wellness even if some skeletal damage is done may well provide an equally strong and reasonable motive for use of biologic agents provided that the data to support this contention are robust and the criteria for improved quality of life are clearly established. In this context, enabling people with SpA to remain in work and maximise their individual productive potential must be seen as key elements for the efficacy of treatment. The balance point must be found between the social cost-benefits of restoring people to good health and productive working lives and the substantial costs and risks of treatment.

\section{Abbreviations}

ACR, American College of Rheumatology; AS, ankylosing spondylitis; ASAS, Assessment of Spondyloarthritis International Society; BASDAI, Bath Ankylosing Spondylitis Disease Activity Index; DMARD, disease-modifying antirheumatoid drug; IL, interleukin; MASES, Maastricht Ankylosing Spondylitis Enthesitis Scale; MRI, magnetic resonance imaging; PASI, Psoriasis Area and Severity Index; PsA, psoriatic arthritis; SF-36, Short-form 36; SpA, spondyloarthritis; TNF, tumour necrosis factor. 


\section{Competing interests}

AK has attended ad hoc boards, has acted as faculty speaker for and received support to attend meetings from Abbott, Schering-Plough (MSD) and Wyeth/ Pfizer. He also has received research funding from Abbott UK. AB decalres that he has no competing interests

Published: 17 December 2010

\section{References}

1. Rudwaleit M, van der Heijde D, Khan MA, Braun J, Sieper J: How to diagnose axial spondyloarthritis early. Ann Rheum Dis 2004, 63:535-543.

2. Rudwaleit M, Schwarzlose S, Hilgert ES, Listing J, Braun J, Sieper J: MRI in predicting a major clinical response to anti-tumour necrosis factor treatment in ankylosing spondylitis. Ann Rheum Dis 2008, 67:1276-1281.

3. Bennett AN, Rehman A, Hensor EM, Marzo-Ortega H, Emery P, McGonagle D: Evaluation of the diagnostic utility of spinal magnetic resonance imaging in axial spondylarthritis. Arthritis Rheum 2009, 60:1331-1341.

4. Wanders A, Heijde D, Landewe R, Behier JM, Calin A, Olivieri I, Zeidler H, Dougados M: Nonsteroidal antiinflammatory drugs reduce radiographic progression in patients with ankylosing spondylitis: a randomized clinical trial. Arthritis Rheum 2005, 52:1756-1765

5. Zochling J, van der Heijde D, Burgos-Vargas R, Collantes E, Davis JC Jr, Dijkmans B, Dougados M, Géher P, Inman RD, Khan MA, Kvien TK, LeirisaloRepo M, Olivieri I, Pavelka K, Sieper J, Stucki G, Sturrock RD, van der Linden S, Wendling D, Böhm H, van Royen BJ, Braun J: ASAS/EULAR recommendations for the management of ankylosing spondylitis. Ann Rheum Dis 2006, 65:442-452.

6. Zochling J, van der Heijde D, Dougados M, Braun J: Current evidence for the management of ankylosing spondylitis: a systematic literature review for the ASAS/EULAR management recommendations in ankylosing spondylitis. Ann Rheum Dis 2006, 65:423-432.

7. Keat A, Hamdulay S: Outcomes in reactive arthritis. In Psoriatic and Reactive Arthritis: A Companion to Rheumatology. Edited by Ritchlin CT, FitzGerald O. Elsevier Mosby; 2007:200-208

8. Sieper J, Rudwaleit M, Baraliakos X, Brandt J, Braun J, Burgos-Vargas R, Dougados M, Hermann KG, Landewe R, Maksymowych W, van der Heijde D: The Assessment of SpondyloArthritis international Society (ASAS) handbook: a guide to assess spondyloarthritis. Ann Rheum Dis 2009, 68(Suppl 2):ii 1-ii44.

9. Gottlieb A, Korman NJ, Gordon KB, Feldman SR, Lebwohl M, Koo JY, Van Voorhees AS, Elmets CA, Leonardi CL, Beutner KR, Bhushan R, Menter A: Guidelines of care for the management of psoriasis and psoriatic arthritis: section 2. Psoriatic arthritis: overview and guidelines of care for treatment with an emphasis on the biologics. J Am Acad Dermatol 2008, 58:851-864.

10. van der Heijde D, Kivitz A, Schiff MH, Sieper J, Dijkmans BA, Braun J, Dougados M, Reveille JD, Wong RL, Kupper H, Davis JC, Jr: Efficacy and safety of adalimumab in patients with ankylosing spondylitis: results of a multicenter, randomized, double-blind, placebo-controlled trial. Arthritis Rheum 2006, 54:2136-2146

11. Braun J, Baraliakos X, Listing J, Fritz C, Alten R, Burmester G, Krause A, Schewe S, Schneider M, Sörensen H, Zeidler H, Sieper J: Persistent clinical efficacy and safety of anti-tumour necrosis factor alpha therapy with infliximab in patients with ankylosing spondylitis over 5 years: evidence for different types of response. Ann Rheum Dis 2008, 67:340-345.

12. Davis JC, Jr, van der Heijde DM, Braun J, Dougados M, Clegg DO, Kivitz AJ, Fleischmann RM, Inman RD, Ni L, Lin SL, Tsuji WH: Efficacy and safety of up to 192 weeks of etanercept therapy in patients with ankylosing spondylitis. Ann Rheum Dis 2008, 67:346-352.

13. van der Heijde D, Schiff MH, Sieper J, Kivitz AJ, Wong RL, Kupper H, Dijkmans BA, Mease PJ, Davis JC, Jr: Adalimumab effectiveness for the treatment of ankylosing spondylitis is maintained for up to 2 years: long-term results from the ATLAS trial. Ann Rheum Dis 2009, 68:922-929.

14. Inman RD, Davis JC Jr, Heijde D, Diekman L, Sieper J, Kim SI, Mack M, Han J, Visvanathan S, Xu Z, Hsu B, Beutler A, Braun J: Efficacy and safety of golimumab in patients with ankylosing spondylitis: results of a randomized, double-blind, placebo-controlled, phase III trial. Arthritis Rheum 2008, 58:3402-3412.

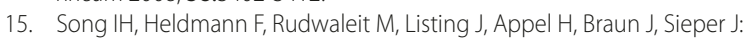
Different response to rituximab in tumor necrosis factor blocker-naive patients with active ankylosing spondylitis and in patients in whom tumor necrosis factor blockers have failed: a twenty-four-week clinical trial.
Arthritis Rheum 2010, 62:1290-1297.

16. Tan AL, Marzo-Ortega H, O'Connor P, Fraser A, Emery P, McGonagle D: Efficacy of anakinra in active ankylosing spondylitis: a clinical and magnetic resonance imaging study. Ann Rheum Dis 2004, 63:1041-1045.

17. Haibel H, Rudwaleit M, Listing J, Sieper J: Open label trial of anakinra in active ankylosing spondylitis over 24 weeks. Ann Rheum Dis 2005, 64:296-298.

18. Sieper J, Baraliakos X, Listing J, Brandt J, Haibel H, Rudwaleit M, Braun J: Persistent reduction of spinal inflammation as assessed by magnetic resonance imaging in patients with ankylosing spondylitis after $2 \mathrm{yrs}$ of treatment with the anti-tumour necrosis factor agent infliximab. Rheumatology (Oxford) 2005, 44:1525-1530.

19. Baraliakos X, Davis J, Tsuji W, Braun J: Magnetic resonance imaging examinations of the spine in patients with ankylosing spondylitis before and after therapy with the tumor necrosis factor alpha receptor fusion protein etanercept. Arthritis Rheum 2005, 52:1216-1223.

20. Lambert RG, Salonen D, Rahman P, Inman RD, Wong RL, Einstein SG, Thomson GT, Beaulieu A, Choquette D, Maksymowych WP: Adalimumab significantly reduces both spinal and sacroiliac joint inflammation in patients with ankylosing spondylitis: a multicenter, randomized, double-blind, placebocontrolled study. Arthritis Rheum 2007, 56:4005-4014.

21. Barkham N, Keen HI, Coates LC, O'Connor P, Hensor E, Fraser AD, Cawkwell LS, Bennett A, McGonagle D, Emery P: Clinical and imaging efficacy of infliximab in HLA-B27-positive patients with magnetic resonance imaging-determined early sacroiliitis. Arthritis Rheum 2009, 60:946-954

22. Haibel H, Rudwaleit M, Listing J, Heldmann F, Wong RL, Kupper H, Braun J, Sieper J: Efficacy of adalimumab in the treatment of axial spondylarthritis without radiographically defined sacroilititis: results of a twelve-week randomized, double-blind, placebo-controlled trial followed by an openlabel extension up to week fifty-two. Arthritis Rheum 2008, 58:1981-1991.

23. Rudwaleit M, Listing J, Brandt J, Braun J, Sieper J: Prediction of a major clinical response (BASDAI 50) to tumour necrosis factor alpha blockers in ankylosing spondylitis. Ann Rheum Dis 2004, 63:665-670.

24. Braun J, Brandt J, Listing J, Zink A, Alten R, Golder W, Gromnica-Ihle E, Kellner H, Krause A, Schneider M, Sörensen H, Zeidler H, Thriene W, Sieper J: Treatment of active ankylosing spondylitis with infliximab: a randomised controlled multicentre trial. Lancet 2002, 359:1187-1193.

25. Brandt J, Khariouzov A, Listing J, Haibel H, Sorensen H, Grassnickel L, Rudwaleit M, Sieper J, Braun J: Six-month results of a double-blind, placebo-controlled trial of etanercept treatment in patients with active ankylosing spondylitis. Arthritis Rheum 2003, 48:1667-1675.

26. National Institute of Health and Clinical Excellence: Adalimumab, etanercept and infliximab for ankylosing spondylitis. In Adalimumab, Etanercept and Infliximab for Ankylosing Spondylitis. NICE Technology Appraisal Guidance 143. London: National Institute of Health and Clinical Excellence; 2008.

27. Boonen A, Brinkhuizen T, Landewe R, van der Heijde D, Severens JL: Impact of ankylosing spondylitis on sick leave, presenteeism and unpaid productivity, and estimation of the societal cost. Ann Rheum Dis 2010, 69:1123-1128

28. Maksymowych WP, Gooch KL, Wong RL, Kupper H, van der Heijde D: Impact of age, sex, physical function, health-related quality of life, and treatment with adalimumab on work status and work productivity of patients with ankylosing spondylitis. J Rheumatol 2010, 37:385-392.

29. van der Heijde D, Han C, DeVlam K, Burmester G, van den Bosch F, Williamson P, Bala M, Han J, Braun J: Infliximab improves productivity and reduces workday loss in patients with ankylosing spondylitis: results from a randomized, placebo-controlled trial. Arthritis Rheum 2006, 55:569-574

30. Keat AC, Gaffney K, Gilbert AK, Harris C, Leeder J: Influence of biologic therapy on return to work in people with work disability due to ankylosing spondylitis. Rheumatology (Oxford) 2008, 47:481-483.

31. Salaffi F, Carotti M, Garofalo G, Giuseppetti GM, Grassi W: Radiological scoring methods for ankylosing spondylitis: a comparison between the Bath Ankylosing Spondylitis Radiology Index and the modified Stoke Ankylosing Spondylitis Spine Score. Clin Exp Rheumatol 2007, 25:67-74

32. Clegg DO, Reda DJ, Weisman MH, Blackburn WD, Cush JJ, Cannon GW, Mahowald ML, Schumacher HR Jr, Taylor T, Budiman-Mak E, Cohen MR, Vasey FB, Luggen ME, Mejias E, Silverman SL, Makkena R, Alepa FP, Buxbaum J, Haakenson CM, Ward RH, Manaster BJ, Anderson RJ, Ward JR, Henderson WG: Comparison of sulfasalazine and placebo in the treatment of ankylosing spondylitis. A Department of Veterans Affairs Cooperative Study. Arthritis Rheum 1996, 39:2004-2012. 
33. Wanders AJ, Landewe RB, Spoorenberg A, Dougados M, van der Linden S, Mielants $\mathrm{H}$, van der Tempel $\mathrm{H}$, van der Heijde DM: What is the most appropriate radiologic scoring method for ankylosing spondylitis? A comparison of the available methods based on the Outcome Measures in Rheumatology Clinical Trials filter. Arthritis Rheum 2004, 50:2622-2632.

34. van der Heijde D, Landewe R, Baraliakos $X$, Houben $H$, van Tubergen A, Williamson P, Xu W, Baker D, Goldstein N, Braun J: Radiographic findings following two years of infliximab therapy in patients with ankylosing spondylitis. Arthritis Rheum 2008, 58:3063-3070.

35. van der Heijde D, Landewe R, Einstein S, Ory P, Vosse D, Ni L, Lin SL, Tsuji W, Davis JC, Jr: Radiographic progression of ankylosing spondylitis after up to two years of treatment with etanercept. Arthritis Rheum 2008, 58:1324-1331.

36. van der Heijde D, Salonen D, Weissman BN, Landewe R, Maksymowych WP, Kupper H, Ballal S, Gibson E, Wong R: Assessment of radiographic progression in the spines of patients with ankylosing spondylitis treated with adalimumab for up to 2 years. Arthritis Res Ther 2009, 11:R127.

37. Braun J, Deodhar A, Dijkmans B, Geusens P, Sieper J, Williamson P, Xu W, Visvanathan S, Baker D, Goldstein N, van der Heijde D: Efficacy and safety of infliximab in patients with ankylosing spondylitis over a two-year period. Arthritis Rheum 2008, 59:1270-1278.

38. van der Heijde DM, Revicki DA, Gooch KL, Wong RL, Kupper H, Harnam N, Thompson C, Sieper J: Physical function, disease activity, and healthrelated quality-of-life outcomes after 3 years of adalimumab treatment in patients with ankylosing spondylitis. Arthritis Res Ther 2009, 11:R124.

39. Baraliakos X, Listing J, Brandt J, Zink A, Alten R, Burmester G, Gromnica-Ihle E, Kellner H, Schneider M, Sörensen H, Zeidler H, Rudwaleit M, Sieper J, Braun J: Clinical response to discontinuation of anti-TNF therapy in patients with ankylosing spondylitis after 3 years of continuous treatment with infliximab. Arthritis Res Ther 2005, 7:R439-R444.

40. Breban M, Ravaud P, Claudepierre P, Baron G, Henry YD, Hudry C, EullerZiegler L, Pham T, Solau-Gervais E, Chary-Valckenaere I, Marcelli C, Perdriger A, Le Loët X, Wendling D, Fautrel B, Fournié B, Combe B, Gaudin P, Jousse S, Mariette X, Baleydier A, Trape G, Dougados M: Maintenance of infliximab treatment in ankylosing spondylitis: results of a one-year randomized controlled trial comparing systematic versus on-demand treatment. Arthritis Rheum 2008, 58:88-97.

41. Lord PA, Farragher TM, Lunt M, Watson KD, Symmons DP, Hyrich KL: Predictors of response to anti-TNF therapy in ankylosing spondylitis: results from the British Society for Rheumatology Biologics Register. Rheumatology (Oxford) 2010, 49:563-570

42. Maksymowych WP, Landewe R, Conner-Spady B, Dougados M, Mielants H, van der Tempel H, Poole AR, Wang N, van der Heijde D: Serum matrix metalloproteinase 3 is an independent predictor of structural damage progression in patients with ankylosing spondylitis. Arthritis Rheum 2007, 56:1846-1853.

43. Coates LC, Cawkwell LS, Ng NW, Bennett AN, Bryer DJ, Fraser AD, Emery P Marzo-Ortega $\mathrm{H}$ : Real life experience confirms sustained response to longterm biologics and switching in ankylosing spondylitis. Rheumatology (Oxford) 2008, 47:897-900.

44. Pradeep DJ, Keat AC, Gaffney K, Brooksby A, Leeder J, Harris C: Switching anti-TNF therapy in ankylosing spondylitis. Rheumatology (Oxford) 2008, 47:1726-1727.

45. Spadaro A, Punzi L, Marchesoni A, Lubrano E, Mathieu A, Cantini F, Olivieri I, Salvarani C, Scarpa R, Scrivo R, Ramonda R, Porru G, D'Angelo S, Catanoso M, Atteno M, Valesini G: Switching from infliximab or etanercept to adalimumab in resistant or intolerant patients with spondyloarthritis: a 4-year study. Rheumatology (Oxford) 2010, 49:1107-1111.

46. Taylor W, Gladman D, Helliwell P, Marchesoni A, Mease P, Mielants H: Classification criteria for psoriatic arthritis: development of new criteria from a large international study. Arthritis Rheum 2006, 54:2665-2673.

47. Gladman DD, Landewé R, McHugh NJ, Fitzgerald O, Thaci D, Coates L, Mease PJ, Qureshi AA, Krueger GG, Ritchlin CT, Kavanaugh AF, Garg A: Composite measures in psoriatic arthritis: GRAPPA 2008. J Rheumato/ 2010, 37:453-461.

48. Ritchlin CT, Kavanaugh A, Gladman DD, Mease PJ, Helliwell P, Boehncke WH, de Vlam K, Fiorentino D, Fitzgerald O, Gottlieb AB, McHugh NJ, Nash P, Qureshi AA, Soriano ER, Taylor WJ; Group for Research and Assessment of Psoriasis and Psoriatic Arthritis (GRAPPA): Treatment recommendations for psoriatic arthritis. Ann Rheum Dis 2009, 68:1387-1394.

49. Ravindran V, Scott DL, Choy EH: A systematic review and meta-analysis of efficacy and toxicity of disease modifying anti-rheumatic drugs and biological agents for psoriatic arthritis. Ann Rheum Dis 2008, 67:855-859.

50. Gladman DD: Adalimumab, etanercept and infliximab are equally effective treatments for patients with psoriatic arthritis. Nat Clin Pract Rheumatol 2008, 4:510-511.

51. Saad AA, Ashcroft DM, Watson KD, Symmons DP, Noyce PR, Hyrich KL: Efficacy and safety of anti-TNF therapies in psoriatic arthritis: an observational study from the British Society for Rheumatology Biologics Register. Rheumatology (Oxford) 2010, 49:697-705

52. Mease PJ, Goffe BS, Metz J, VanderStoep A, Finck B, Burge DJ: Etanercept in the treatment of psoriatic arthritis and psoriasis: a randomised trial. Lancet 2000, 356:385-390

53. Mease PJ, Kivitz AJ, Burch FX, Siegel EL, Cohen SB, Ory P, Salonen D, Rubenstein J, Sharp JT, Tsuji W: Etanercept treatment of psoriatic arthritis: safety, efficacy, and effect on disease progression. Arthritis Rheum 2004, 50:2264-2272.

54. Antoni CE, Kavanaugh A, Kirkham B, Tutuncu Z, Burmester GR, Schneider U, Furst DE, Molitor J, Keystone E, Gladman D, Manger B, Wassenberg S, Weier R, Wallace DJ, Weisman MH, Kalden JR, Smolen J: Sustained benefits of infliximab therapy for dermatologic and articular manifestations of psoriatic arthritis: results from the infliximab multinational psoriatic arthritis controlled trial (IMPACT). Arthritis Rheum 2005, 52:1227-1236

55. Mease PJ, Gladman DD, Ritchlin CT, Ruderman EM, Steinfeld SD, Choy EH, Sharp JT, Ory PA, Perdok RJ, Weinberg MA: Adalimumab for the treatment of patients with moderately to severely active psoriatic arthritis: results of a double-blind, randomized, placebo-controlled trial. Arthritis Rheum 2005, 52:3279-3289.

56. Kavanaugh A, McInnes I, Mease P, Krueger GG, Gladman D, Gomez-Reino J, Papp K, Zrubek J, Mudivarthy S, Mack M, Visvanathan S, Beutler A: Golimumab, a new human tumor necrosis factor alpha antibody, administered every four weeks as a subcutaneous injection in psoriatic arthritis: twenty-four-week efficacy and safety results of a randomized, placebo-controlled study. Arthritis Rheum 2009, 60:976-986.

57. Spadaro A, Ceccarelli F, Scrivo R, Valesini G: Life-table analysis of etanercept with or without methotrexate in patients with psoriatic arthritis. Ann Rheum Dis 2008, 67:1650-1651.

58. Conti F, Ceccarelli F, Marocchi E, Magrini L, Spinelli FR, Spadaro A, Scrivo R, Valesini G: Switching tumour necrosis factor alpha antagonists in patients with ankylosing spondylitis and psoriatic arthritis: an observational study over a 5-year period. Ann Rheum Dis 2007, 66:1393-1397.

59. Antoni C, Krueger GG, de Vlam K, Birbara C, Beutler A, Guzzo C, Zhou B, Dooley LT, Kavanaugh A: Infliximab improves signs and symptoms of psoriatic arthritis: results of the IMPACT 2 trial. Ann Rheum Dis 2005, 64:1150-1157.

60. Mease PJ, Ory P, Sharp JT, Ritchlin CT, Van den Bosch F, Wellborne F, Birbara C, Thomson GT, Perdok RJ, Medich J, Wong RL, Gladman DD: Adalimumab for long-term treatment of psoriatic arthritis: 2-year data from the Adalimumab Effectiveness in Psoriatic Arthritis Trial (ADEPT). Ann Rheum Dis 2009, 68:702-709.

61. Antoni CE, Kavanaugh A, van der Heijde D, Beutler A, Keenan G, Zhou B, Kirkham B, Tutuncu Z, Burmester GR, Schneider U, Furst DE, Molitor J, Keystone E, Gladman DD, Manger B, Wassenberg S, Weier R, Wallace DJ, Weisman MH, Kalden JR, Smolen JS: Two-year efficacy and safety of infliximab treatment in patients with active psoriatic arthritis: findings of the Infliximab Multinational Psoriatic Arthritis Controlled Trial (IMPACT). $J$ Rheumatol 2008, 35:869-876.

62. Kavanaugh A, Krueger GG, Beutler A, Guzzo C, Zhou B, Dooley LT, Mease PJ Gladman DD, de Vlam K, Geusens PP, Birbara C, Halter DG, Antoni C; IMPACT 2 Study Group: Infliximab maintains a high degree of clinical response in patients with active psoriatic arthritis through 1 year of treatment: results from the IMPACT 2 trial. Ann Rheum Dis 2007, 66:498-505.

63. Saad AA, Ashcroft DM, Watson KD, Symmons DP, Noyce PR, Hyrich KL: Improvements in quality of life and functional status in patients with psoriatic arthritis receiving anti-tumor necrosis factor therapies. Arthritis Care Res (Hoboken) 2010, 62:345-353.

64. Mease PJ, Kivitz AJ, Burch FX, Siegel EL, Cohen SB, Ory P, Salonen D, Rubenstein J, Sharp JT, Dunn M, Tsuji W: Continued inhibition of radiographic progression in patients with psoriatic arthritis following 2 years of treatment with etanercept. J Rheumato/ 2006, 33:712-721.

65. van der Heijde D, Kavanaugh A, Gladman DD, Antoni C, Krueger GG, Guzzo C, Zhou B, Dooley LT, de Vlam K, Geusens P, Birbara C, Halter D, Beutler A: Infliximab inhibits progression of radiographic damage in patients with 
active psoriatic arthritis through one year of treatment: results from the induction and maintenance psoriatic arthritis clinical trial 2. Arthritis Rheum 2007, 56:2698-2707

66. Gladman DD, Mease PJ, Ritchlin CT, Choy EH, Sharp JT, Ory PA, Perdok RJ, Sasso EH: Adalimumab for long-term treatment of psoriatic arthritis: fortyeight week data from the adalimumab effectiveness in psoriatic arthritis trial. Arthritis Rheum 2007, 56:476-488.

67. Carter JD, Espinoza LR, Inman RD, Sneed KB, Ricca LR, Vasey FB, Valeriano J, Stanich JA, Oszust C, Gerard HC, Hudson AP: Combination antibiotics as a treatment for chronic Chlamydia-induced reactive arthritis: a doubleblind, placebo-controlled, prospective trial. Arthritis Rheum 2010, 62:1298-1307

68. Oili KS, Niinisalo H, Korpilahde T, Virolainen J: Treatment of reactive arthritis with infliximab. Scand J Rheumato/ 2003, 32:122-124.

69. Dougados M, van der Linden S, Juhlin R, Huitfeldt B, Amor B, Calin A, Cats A, Dijkmans B, Olivieri I, Pasero G, Veys E, Zeidler H: The European Spondylarthropathy Study Group preliminary criteria for the classification of spondylarthropathy. Arthritis Rheum 1991, 34:1218-1227.

70. Rudwaleit M, Claudepierre P, Kron M, Kary S, Wong R, Kupper H: Effectiveness of adalimumab in treating patients with ankylosing spondylitis associated with enthesitis and peripheral arthritis. Arthritis Res Ther 2010, 12:R43.

71. van der Heijde D, Dijkmans B, Geusens P, Sieper J, DeWoody K, Williamson P, Braun J: Efficacy and safety of infliximab in patients with ankylosing spondylitis: results of a randomized, placebo-controlled trial (ASSERT). Arthritis Rheum 2005, 52:582-591.

72. Schatteman L, Gyselbrecht L, De Clercq L, Mielants H: Treatment of refractory inflammatory monoarthritis in ankylosing spondylitis by intraarticular injection of infliximab. J Rheumatol 2006, 33:82-85.

73. Rudwaleit M, Haibel H, Baraliakos X, Listing J, Marker-Hermann E, Zeidler H, Braun J, Sieper J: The early disease stage in axial spondylarthritis: results from the German Spondyloarthritis Inception Cohort. Arthritis Rheum 2009, 60:717-727.

74. Vander Cruyssen B, Ribbens C, Boonen A, Mielants H, de Vlam K, Lenaerts J, Steinfeld S, Van den Bosch F, Dewulf L, Vastesaeger N: The epidemiology of ankylosing spondylitis and the commencement of anti-TNF therapy in daily rheumatology practice. Ann Rheum Dis 2007, 66:1072-1077.

75. Sidiropoulos PI, Hatemi G, Song IH, Avouac J, Collantes E, Hamuryudan V, Herold M, Kvien TK, Mielants H, Mendoza JM, Olivieri I, Østergaard M, Schachna L, Sieper J, Boumpas DT, Dougados M: Evidence-based recommendations for the management of ankylosing spondylitis: systematic literature search of the $3 E$ Initiative in Rheumatology involving a broad panel of experts and practising rheumatologists. Rheumatology (Oxford) 2008, 47:355-361.

76. Braun J, Baraliakos X, Listing J, Sieper J: Decreased incidence of anterior uveitis in patients with ankylosing spondylitis treated with the anti-tumor necrosis factor agents infliximab and etanercept. Arthritis Rheum 2005, 52:2447-2451

77. Rudwaleit M, Rødevand E, Holck P, Vanhoof J, Kron M, Kary S, Kupper H: Adalimumab effectively reduces the rate of anterior uveitis flares in patients with active ankylosing spondylitis: results of a prospective openlabel study. Ann Rheum Dis 2009, 68:696-701.

78. Gottlieb A, Menter A, Mendelsohn A, Shen YK, Li S, Guzzo C, Fretzin S, Kunynetz R, Kavanaugh A: Ustekinumab, a human interleukin 12/23 monoclonal antibody, for psoriatic arthritis: randomised, double-blind, placebo-controlled, crossover trial. Lancet 2009, 373:633-640.

79. Papp KA, Langley RG, Lebwohl M, Krueger GG, Szapary P, Yeilding N, Guzzo C, Hsu MC, Wang Y, Li S, Dooley LT, Reich K; PHOENIX 2 study investigators: Efficacy and safety of ustekinumab, a human interleukin-12/23 monoclonal antibody, in patients with psoriasis: 52 -week results from a randomised, double-blind, placebo-controlled trial (PHOENIX 2). Lancet 2008, 371:1675-1684.

80. Mclnnes IB, Illei GG, Danning CL, Yarboro CH, Crane M, Kuroiwa T, Schlimgen R, Lee E, Foster B, Flemming D, Prussin C, Fleisher TA, Boumpas DT: IL-10 improves skin disease and modulates endothelial activation and leukocyte effector function in patients with psoriatic arthritis. J Immunol 2001, 167:4075-4082.

81. Krueger GG, Papp KA, Stough DB, Loven KH, Gulliver WP, Ellis CN: A randomized, double-blind, placebo-controlled phase III study evaluating efficacy and tolerability of 2 courses of alefacept in patients with chronic plaque psoriasis. J Am Acad Dermatol 2002, 47:821-833.

82. Mease PJ, Reich K: Alefacept with methotrexate for treatment of psoriatic arthritis: open-label extension of a randomized, double-blind, placebocontrolled study. J Am Acad Dermato/ 2009, 60:402-411.

83. Menter A, Gottlieb A, Feldman SR, Van Voorhees AS, Leonardi CL, Gordon KB, Lebwohl M, Koo JY, Elmets CA, Korman NJ, Beutner KR, Bhushan R: Guidelines of care for the management of psoriasis and psoriatic arthritis: section 1. Overview of psoriasis and guidelines of care for the treatment of psoriasis with biologics. J Am Acad Dermatol 2008, 58:826-850.

84. van Eijk IC, de Vries MK, Levels JH, Peters MJ, Huizer EE, Dijkmans BA, van der Horst-Bruinsma IE, Hazenberg BP, van de Stadt RJ, Wolbink GJ, Nurmohamed MT: Improvement of lipid profile is accompanied by atheroprotective alterations in high-density lipoprotein composition upon tumor necrosis factor blockade: a prospective cohort study in ankylosing spondylitis. Arthritis Rheum 2009, 60:1324-1330.

85. Osting VC, Carter JD: A safety assessment of tumor necrosis factor antagonists during pregnancy. Expert Opin Drug Saf 2010, 9:421-429.

86. Braun J, Davis J, Dougados M, Sieper J, van der Linden S, van der Heijde D: First update of the international ASAS consensus statement for the use of anti-TNF agents in patients with ankylosing spondylitis. Ann Rheum Dis 2006, 65:316-320.

87. Keat A, Barkham N, Bhalla A, Gaffney K, Marzo-Ortega H, Paul S, Rogers F, Somerville M, Sturrock R, Wordsworth P: BSR guidelines for prescribing TNF-alpha blockers in adults with ankylosing spondylitis. Report of a working party of the British Society for Rheumatology. Rheumatology (Oxford) 2005, 44:939-947.

88. Kyle S, Chandler D, Griffiths CE, Helliwell P, Lewis J, McInnes I, Oliver S, Symmons D, McHugh N: Guideline for anti-TNF-alpha therapy in psoriatic arthritis. Rheumatology (Oxford) 2005, 44:390-397.

89. National Institute for Health and Clinical Excellence: Etanercept and Infliximab for the Treatment of Psoriatic Arthritis. London: National Institute of Health and Clinical Excellence; 2006.

90. National Institute for Health and Clinical Excellence: Adalimumab for the Treatment of Psoriatic Arthritis. Technology appraisals TA125. London: National Institute of Health and Clinical Excellence; 2007.

91. Rudwaleit M, van der Heijde D, Landewé R, Listing J, Akkoc N, Brandt J, Braun J, Chou CT, Collantes-Estevez E, Dougados M, Huang F, Gu J, Khan MA, Kirazli Y, Maksymowych WP, Mielants H, Sørensen IJ, Ozgocmen S, Roussou E, ValleOñate R, Weber U, Wei J, Sieper J: The development of Assessment of SpondyloArthritis international Society classification criteria for axial spondyloarthritis (part II): validation and final selection. Ann Rheum Dis 2009, 68:777-783.

92. Martin Mola E, Sieper J, Leirisalo-Repo M, Dijkmans BA, Vlahos B, Pedersen R, Koenig AS, Freundlich B: Sustained efficacy and safety, including patientreported outcomes, with etanercept treatment over 5 years in patients with ankylosing spondylitis. Clin Exp Rheumatol 2010, 28:238-245.

93. Braun J, Baraliakos X, Brandt J, Listing J, Zink A, Alten R, Burmester G, Gromnica-Ihle E, Kellner H, Schneider M, Sörensen H, Zeidler H, Sieper J: Persistent clinical response to the anti-TNF-alpha antibody infliximab in patients with ankylosing spondylitis over 3 years. Rheumatology (Oxford) 2005, 44:670-676.

94. Braun J, Brandt J, Listing J, Zink A, Alten R, Burmester G, Golder W, GromnicaIhle E, Kellner H, Schneider M, Sörensen H, Zeidler H, Reddig J, Sieper J: Longterm efficacy and safety of infliximab in the treatment of ankylosing spondylitis: an open, observational, extension study of a three-month, randomized, placebo-controlled trial. Arthritis Rheum 2003, 48:2224-2233.

95. Braun J, Brandt J, Listing J, Zink A, Alten R, Burmester G, Gromnica-Ihle E, Kellner H, Schneider M, Sörensen H, Zeidler H, Sieper J: Two year maintenance of efficacy and safety of infliximab in the treatment of ankylosing spondylitis. Ann Rheum Dis 2005, 64:229-234.

96. Calin A, Dijkmans BA, Emery P, Hakala M, Kalden J, Leirisalo-Repo M, Mola EM, Salvarani C, Sanmartí R, Sany J, Sibilia J, Sieper J, van der Linden S, Veys E, Appel AM, Fatenejad S: Outcomes of a multicentre randomised clinical trial of etanercept to treat ankylosing spondylitis. Ann Rheum Dis 2004 63:1594-1600.

97. Dijkmans B, Emery P. Hakala M, Leirisalo-Repo M, Mola EM, Paolozzi L, Salvarani C, Sanmarti R, Sibilia J, Sieper J, Van Den Bosch F, van der Heijde D, van der Linden S, Wajdula J: Etanercept in the longterm treatment of patients with ankylosing spondylitis. J Rheumato/ 2009, 36:1256-1264.

98. Brandt J, Listing J, Haibel H, Sorensen H, Schwebig A, Rudwaleit M, Sieper J, Braun J: Long-term efficacy and safety of etanercept after readministration in patients with active ankylosing spondylitis. Rheumatology (Oxford) 2005, 44:342-348. 
99. Garrett S, Jenkinson T, Kennedy LG, Whitelock H, Gaisford P, Calin A: A new approach to defining disease status in ankylosing spondylitis: the Bath Ankylosing Spondylitis Disease Activity Index. J Rheumato/ 1994, 21:2286-2291.

100. Anderson JJ, Baron G, van der Heijde D, Felson DT, Dougados M: Ankylosing spondylitis assessment group preliminary definition of short-term improvement in ankylosing spondylitis. Arthritis Rheum 2001, 44:1876-1886.

101. Brandt J, Listing J, Sieper J, Rudwaleit M, van der Heijde D, Braun J: Development and preselection of criteria for short term improvement after anti-TNF alpha treatment in ankylosing spondylitis. Ann Rheum Dis 2004, 63:1438-1444.

102. Lukas C, Landewe R, Sieper J, Dougados M, Davis J, Braun J, van der Linden S, van der Heijde D: Development of an ASAS-endorsed disease activity score (ASDAS) in patients with ankylosing spondylitis. Ann Rheum Dis 2009, 68:18-24.

103. Calin A, Garrett S, Whitelock H, Kennedy LG, O'Hea J, Mallorie P, Jenkinson T: A new approach to defining functional ability in ankylosing spondylitis: the development of the Bath Ankylosing Spondylitis Functional Index. J Rheumatol 1994, 21:2281-2285.

104. Dougados M, Gueguen A, Nakache JP, Nguyen M, Mery C, Amor B: Evaluation of a functional index and an articular index in ankylosing spondylitis. J Rheumatol 1988, 15:302-307.

105. Daltroy LH, Larson MG, Roberts NW, Liang MH: A modification of the Health Assessment Questionnaire for the spondyloarthropathies. J Rheumatol 1990, 17:946-950.

106. Jenkinson TR, Mallorie PA, Whitelock HC, Kennedy LG, Garrett SL, Calin A: Defining spinal mobility in ankylosing spondylitis (AS). The Bath AS Metrology Index. J Rheumato/ 1994, 21:1694-1698.

107. Maksymowych WP, Mallon C, Richardson R, Conner-Spady B, Jauregui E, Chung C, Zappala L, Pile K, Russell AS: Development and validation of the Edmonton Ankylosing Spondylitis Metrology Index. Arthritis Rheum 2006, 55:575-582

108. Creemers MC, Franssen MJ, van't Hof MA, Gribnau FW, van de Putte LB, van Riel PL: Assessment of outcome in ankylosing spondylitis: an extended radiographic scoring system. Ann Rheum Dis 2005, 64:127-129.

109. Haibel H, Rudwaleit M, Brandt HC, Grozdanovic Z, Listing J, Kupper H, Braun J, Sieper J: Adalimumab reduces spinal symptoms in active ankylosing spondylitis: clinical and magnetic resonance imaging results of a fifty-twoweek open-label trial. Arthritis Rheum 2006, 54:678-681.

110. Braun J, Baraliakos X, Golder W, Brandt J, Rudwaleit M, Listing J, Bollow M, Sieper J, Van Der Heijde D: Magnetic resonance imaging examinations of the spine in patients with ankylosing spondylitis, before and after successful therapy with infliximab: evaluation of a new scoring system. Arthritis Rheum 2003, 48:1126-1136.
111. Maksymowych WP, Inman RD, Salonen D, Dhillon SS, Krishnananthan R, Stone M, Conner-Spady B, Palsat J, Lambert RG: Spondyloarthritis Research Consortium of Canada magnetic resonance imaging index for assessment of spinal inflammation in ankylosing spondylitis. Arthritis Rheum 2005, 53:502-509.

112. Gilworth G, Emery P, Barkham N, Smyth MG, Helliwell P, Tennant A: Reducing work disability in ankylosing spondylitis: development of a work instability scale for AS. BMC Musculoskelet Disord 2009, 10:68.

113. Prasad M, Wahlqvist $P$, Shikiar $R$, Shih YC: A review of self-report instruments measuring health-related work productivity: a patient-reported outcomes perspective. Pharmacoeconomics 2004, 22:225-244.

114. Doward LC, Spoorenberg A, Cook SA, Whalley D, Helliwell PS, Kay LJ, McKenna SP, Tennant A, van der Heijde D, Chamberlain MA: Development of the ASQoL: a quality of life instrument specific to ankylosing spondylitis. Ann Rheum Dis 2003, 62:20-26.

115. Ware JE: SF-36 Health Survey: Manual and Interpretation Guide. Lincoln, Rl: QualityMetric Inc.; 2000

116. Felson DT, Anderson JJ, Boers M, Bombardier C, Furst D, Goldsmith C, Katz LM, Lightfoot R Jr, Paulus H, Strand V, Tugwell P, Weinblatt M, Williams HJ, Wolfe F, Kieszak S: American College of Rheumatology. Preliminary definition of improvement in rheumatoid arthritis. Arthritis Rheum 1995, 38:727-735.

117. Clegg DO, Reda DJ, Mejias E, Cannon GW, Weisman MH, Taylor T, BudimanMak E, Blackburn WD, Vasey FB, Mahowald ML, Cush JJ, Schumacher HR Jr, Silverman SL, Alepa FP, Luggen ME, Cohen MR, Makkena R, Haakenson CM, Ward RH, Manaster BJ, Anderson RJ, Ward JR, Henderson WG: Comparison of sulfasalazine and placebo in the treatment of psoriatic arthritis. A Department of Veterans Affairs Cooperative Study. Arthritis Rheum 1996, 39:2013-2020.

118. Fredriksson T, Pettersson U: Severe psoriasis - oral therapy with a new retinoid. Dermatologica 1978, 157:238-244.

119. Coates LC, Fransen J, Helliwell PS: Defining minimal disease activity in psoriatic arthritis: a proposed objective target for treatment. Ann Rheum Dis 2010, 69:48-53.

120. Sharp JT, Lidsky MD, Collins LC, Moreland J: Methods of scoring the progression of radiologic changes in rheumatoid arthritis. Correlation of radiologic, clinical and laboratory abnormalities. Arthritis Rheum 1971, 14:706-720.

doi:10.1186/ar3178

Cite this article as: Barr A, Keat A: Spondyloarthritides: evolving therapies. Arthritis Research \& Therapy 2010, 12:221. 